\title{
Uji daya hambat ekstrak daun cengkih (Syzygium aromaticum (L.)) terhadap bakteri Enterococcus faecalis
}

\author{
${ }^{1}$ Eskha M. Lambiju \\ ${ }^{2}$ Pemsi M. Wowor \\ ${ }^{3}$ Michael A. Leman \\ ${ }^{1}$ Kandidat Skripsi Program Studi Pendidikan Dokter Gigi Fakultas Kedokteran \\ ${ }^{2}$ Bagian Farmakologi dan Terapi Fakultas Kedokteran \\ ${ }^{3}$ Program Studi Pendidikan Dokter Gigi Fakultas Kedokteran \\ Universitas Sam Ratulangi Manado \\ Email: Eskhamaritje@yahoo.com
}

\begin{abstract}
Cloves (Syzygium aromaticum L.) grow widely in Indonesia. This plant has many benefits from its stem, leaves, and flowers. Clove leaves has several antibacterial compounds such as flavonoids, tannins, and triterpenoids, as well as eugenol as the major component of essential oil. Enterococcus faecalis is a facultative anaerobic Gram positive bacteria and normal flora in the mouth. These bacteria are often identified as the cause of the failure of root canal treatment. This study was aimed to determine the effectiveness of clove in inhibiting the growth of bacteria Enterococcus faecalis. This was an experimental study with a modified method of Kirby-Bauer using pits. Samples of clove leaves were obtained from Treman, North Minahasa, and then were extracted by using maceration method with $96 \%$ ethanol. Metronidazole was used as positive control. Enterococcus faecalis bacteria were taken from the direct isolation of patients' necrotic teeth. The results showed that the average inhibition zone of clove leaf extract against Enterococuss faecalis was $8.0 \mathrm{~mm}$ meanwhile of metronidazole was $10.0 \mathrm{~mm}$. Conclusion: Clove leaf extract had moderate inhibitory effect against the growth of Enterococcus faecalis.
\end{abstract}

Keywords: clove leaves, Enterococcus faecalis, inhibition.

\begin{abstract}
Abstrak: Tanaman cengkih (Syzygium Aromaticum L.) banyak tumbuh di Indonesia. Tanaman ini memiliki banyak manfaat mulai dari batang, daun, dan bunga. Daun cengkih mengandung berbagai senyawa yang bersifat antibakteri seperti flavonoid, tannin, dan triterpenoid, serta senyawa eugenol yang merupakan komponen utama dalam minyak atrisi. Enterococcus faecalis ialah bakteri Gram positif fakultatif anaerob yang merupakan flora normal dalam mulut. Bakteri ini sering terisolasi sebagai penyebab kegagalan perawatan saluran akar. Penelitian ini bertujuan untuk mengetahui daya hambat daun cengkih (Syzygium Aromaticum L.) terhadap pertumbuhan bakteri Enterococcus faecalis. Jenis penelitian ialah eksperimental dengan metode modifikasi Kirby-Bauer menggunakan sumuran. Sampel daun cengkeh diperoleh dari daerah Treman Kabupaten Minahasa Utara yang kemudian diekstrasi dengan metode maserasi menggunakan etanol 96\%. Sebagai kontrol positif diginakan metronidazole. Bakteri Enterococcus faecalis diambil dari isolasi langsung pada pasien dengan gigi nekrosis. Hasil penelitian ini mendapatkan rerata zona inhibisi ekstrak daun cengkih terhadap bakteri Enterococuss faecalis sebesar $8,0 \mathrm{~mm}$ sedangkan zona inhibisi metronidazole 13,0 mm. Simpulan: Ekstrak daun cengkih memiliki daya hambat yang tergolong sedang terhadap pertumbuhan bakteri Enterococcus faecalis.
\end{abstract}

Kata kunci: daun cengkih, Enterococcus faecalis, daya hambat 
Perawatan saluran akar merupakan perawatan pada gigi berlubang dengan mengangkat seluruh jaringan pulpa yang telah terinfeksi bakteri. ${ }^{1}$ Perawatan saluran akar bertujuan untuk mempertahankan gigi agar tetap berada dalam alveolus gigi dan dapat berfungsi dengan baik tanpa dilakukan pencabutan. ${ }^{2}$

Kegagalan perawatan saluran akar dapat dipengaruhi oleh beberapa faktor yaitu kesalahan diagnosis, rencana perawatan, serta kegagalan prosedur. $^{3}$ Selain itu, salah satu penyebab kegagalan perawatan saluran akar yaitu adanya mikroorganisme. Dari berbagai hasil penelitian didapatkan bahwa mikroorganisme yang sering diisolasi pada kegagalan perawatan saluran akar ialah bakteri Enterococcus faecalis, ${ }^{4}$ yang merupakan bakteri fakultatif Gram positif berwarna ungu. ${ }^{5}$ Hampir $90 \%$ infeksi pada saluran akar disebabkan oleh bakteri tersebut. Bakteri ini juga resisten terhadap beberapa antibiotik seperti aminoglikosida, peninsilin, tetrasiklin, vankomisin, dan terhadap kalsium hidroksida yang merupakan medikamen yang sering dipakai dalam perawatan saluran akar. ${ }^{6,7}$

Indonesia memiliki banyak jenis tanaman yang sering dijadikan sebagai obat herbal, salah satunya ialah cengkih. Provinsi Sulawesi Utara merupakan daerah penghasil cengkih terbesar dan sering dijadikan sebagai barometer nasional. ${ }^{8}$ Batang, daun, dan bunga dari tanaman cengkih memiliki banyak manfaat. Daun cengkih juga sering dimanfaatkan sebagai sumber minyak cengkih; hal ini disebabkan minyak cengkih mengandung senyawa etanol yang memiliki kandungan flavonoid, tanin, fenolat, dan minyak atsiri yang memiliki sifat sebagai antiseptik, analgesik, antiinflamasi, antijamur, antibakteri. ${ }^{9}$ Daun cengkih saat ini belum sepenuhnya dimanfaatkan dalam bidang pengobatan. Daun cengkih lebih sering digunakan sebagai bahan utama dari produksi rokok kretek dan menjadi limbah yang dibiarkan begitu saja. Menurut penelitian yang dilakukan oleh Haryani, ${ }^{10}$ ekstrak daun cengkih mengandung berbagai seyawa- senyawa seperti flavonoid, triterpenoid, fenolat, tannin yang merupakan senyawa bersifat antibakteri yang telah terbukti dapat menurunkan aktivitas bakteri.

Berdasarkan latar belakang di atas, peneliti tertarik untuk meneliti ekstrak daun cengkih dalam menghambat pertumbuhan Enterococcus faecalis.

\section{BAHAN DAN METODE PENELITIAN}

Jenis penelitian ini ialah eksperimental murni (true experimental design) dengan posttest only control group design. Penelitian ini dilaksanakan di Laboratorium Farmasi Fakultas MIPA dan Laboratorium Mikrobiologi Fakultas Kedokteran, Universitas Sam Ratulangi Manado pada bulan November 2016.

Bahan-bahan yang digunakan dalam penelitian ini ialah ekstrak daun cengkih, bakteri Entrecoccus faecalis, brain heart infusion broth (BHI-B), nutrient agar (NA), Muller-Hinton agar (MHA), larutan $\mathrm{BaCl} 2$ $1 \%$, larutan $\mathrm{H} 2 \mathrm{SO} 41 \%$, kertas saring, aquades steril, metrodinazole $500 \mathrm{mg}$, dan etanol 96\%. Alat-alat yang digunakan dalam penelitian ini ialah cawan Petri $(\mathrm{d}=$ $9 \mathrm{~cm}$ ), tabung erlenmeyer, tabung reaksi, pinset, mikropipet, kapas lidi steril, batang pengaduk, inkubator, vacuum rotary evaporator, autoklaf, timbangan digital, api Bunsen, jangka sorong (bahan besi), sendok, masker, sarung tangan, spidol, kamera, oven, kompor, blender, dan mistar berskala milimeter $(\mathrm{mm})$.

Subjek penelitian ini ialah bakteri Enterococcus faecalis. Ekstrak daun cengkih diperoleh dengan cara ekstraksi menggunakan metode maserasi dengan pelarut etanol 96\%. Sampel daun cengkih diperoleh di daerah Treman, Kecamatan Airmadidi Kabupaten Minahasa Utara. Metode pengujian yang digunakan ialah modifikasi metode Kirby-Bauer dengan menggunakan sumuran. Cawan Petri dibuat 3 sumur; sumur I diisi dengan larutan ekstrak daun cengkih, sumur II diisi metrodinazole sebagai kontrol positif, dan sumur III diisi aquades steril sebagai kontrol negatif.

Bakteri Enterococcus faecalis yang 
digunakan dalam penelitian ini diambil dari stok bakteri murni dari Laboratorium Mikrobiologi Farmasi Fakultas MIPA, kemudian dibiakan di Laboratorium Mikrobiologi Fakultas Kedokteran, Universitas Sam Ratulangi Manado. Bakteri ini disimpan pada media Brain Heart Infusion Broth (BHI-B) kemudian dimasukkan ke dalam wadah steril yang berada dalam suasana anaerob dan diinkubasi pada suhu $37^{0} \mathrm{C}$ selama 24 jam. Media peremajaam dasar menggunakan Nutrient Agar (NA) dan media pembenihan menggunakan Agar Muller-Hilton (MHA). Sebagai kontrol positif ialah sediaan metrodinazole dalam bentuk tablet dengan pelarut aquades.

\section{HASIL PENELITIAN}

Penelitian ini menunjukkan terdapat daya hambat ekstrak daun cengkih (Syzygium Aromaticum L.) terhadap bakteri Enterococcus faecalis. Hal ini dinyatakan dengan terbentuknya zona bening di sekitar sumur yang berisi ekstrak daun cengkih (Gambar 1).

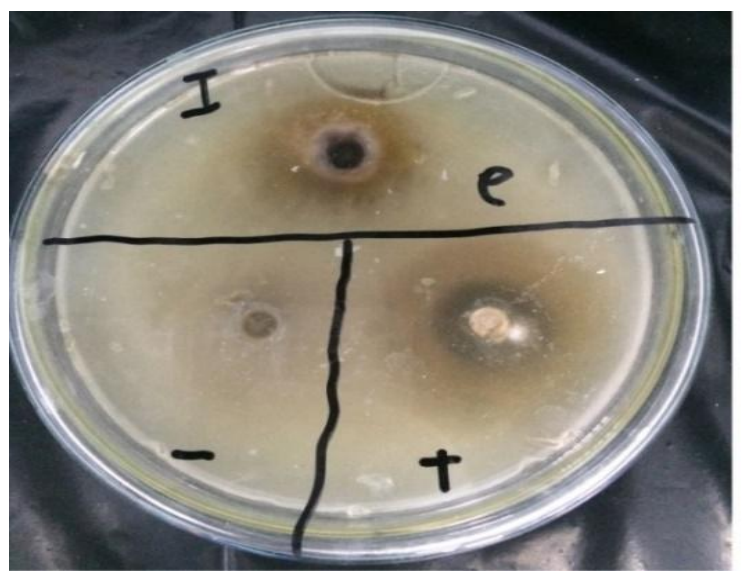

Gambar 1. Zona hambat yang terbentuk pada media MHA

Keterangan :

E : Sumuran yang berisikan ekstrak daun cengkih

+ : Sumuran yang berisikan larutan metrodinazole sebagai kontrol posotif

- : Sumuran yang berisikan aquades steril sebagai kontrol negatif.

Zona hambat yang dihasilkan masingmasing perlakuan memiliki diameter berbeda-beda. Pengamatan dilakukan dengan cara mengukur diameter horizontal dan diameter vertikal dari zona hambat yang terbentuk kemudian dimasukkan ke dalam rumus untuk mencari rerata zona hambat kemudian dimasukkan pada tabel kerja. Tabel 1 menunjukkan diameter rerata zona hambat pada ekstrak daun cengkih sebesar $8 \mathrm{~mm}$ dan pada metrodinazol sebagai kontrol positif sebesar 13,0 mm. Aquades sebagai kontrol negatif tidak menunjukkan adanya zona hambat.

Tabel 1. Diameter zona hambat daun cengkih (Syzygium Aromaticum (L.) ), metrodinazile, dan aquades steril.

\begin{tabular}{cccc}
\hline \multirow{2}{*}{$\begin{array}{c}\text { Cawan } \\
\text { Petri }\end{array}$} & \multicolumn{3}{c}{ Diameter zona hambat (mm) } \\
\cline { 2 - 4 } & $\begin{array}{c}\text { Ekstrak } \\
\text { daun } \\
\text { cengkih }\end{array}$ & $\begin{array}{c}\text { Metrodinazole } \\
\text { (kontrol +) }\end{array}$ & $\begin{array}{c}\text { Aquades } \\
\text { steril } \\
\text { (kontrol -) }\end{array}$ \\
\hline I & 9 & 14,0 & 0,0 \\
II & 7,5 & 13,0 & 0,0 \\
III & 7 & 12,0 & 0,0 \\
IV & 8 & 12,5 & 0,0 \\
V & 8,5 & 13,5 & 0,0 \\
Rerata & 8 & 13,0 & 0,0 \\
\hline
\end{tabular}

\section{BAHASAN}

Hasil penelitian ini menunjukkan bahwa ekstrak daun cengkih (Syzygium Aromaticum L.) dapat menghambat pertumbuhan bakteri Enterococcus faecalis. Pengukuran diameter zona hambat dapat digolongkan berdasarkan kategori kekuatan zona hambat. Rerata diameter zona hambat yang dihasilkan ekstrak daun cengkih sebesar $8 \mathrm{~mm}$ yang tergolong pada kategori sedang dalam menghambat pertumbuhan bakteri Enterococcus faecalis. Jika dibandingkan dengan zona hambat pada antibiotik metrodinazole, ekstrak daun cengkih lebih kecil sedangkan pada sumur yang diberi aquades steril tidak menunjukkan adanya zona hambat.

Zona hambat yang dihasilkan oleh antibiotik metrodinazole lebih besar dibandingkan dengan zona hambat ekstrak daun cengkih karena metrodinazole merupakan antibiotik dengan spektrum luas dan memiliki aktivitas antibakteri anaerob. Mekanisme kerja metrodinazole yaitu menghambat sintesis asam nukleat yang 
dapat mengakibatkan kematian sel bakteri. $^{11}$ Selain antibiotik metrodinazole terdapat beberapa antibiotik yang biasa digunakan untuk menghambat bakteri Enterococcus faecalis, antara lain kholorheksidin.

Zona hambat yang terbentuk disebabkan adanya zat-zat aktif pada daun cengkih mengandung senyawa yang bersifat antibakteri seperti flavonoid, tannin, saponin, terpenoid, dan fenol. Mekanisme kerja flavonoid sebagai antiabkteri dengan cara membentuk senyawa kompleks terhadap protein ekstrasel yang menganggu keutuhan membran sel bakteri dan merusak membran sel tanpa memperbaikinya lagi. ${ }^{12}$ Tanin merupakan senyawa yang banyak dijumpai pada tumbuhan. Tanin memiliki aktivitas antibakteri dengan mekanisme kerjanya merusak membran sel bakteri. ${ }^{13}$ Triterpenoid merupakan senyawa metabolit sekunder dengan mekanisme kerja sebagai antibakteri yang beraksi dengan porin (protein transmembran) pada membran luar dinding sel bakteri, membentuk ikatan polimer yang kuat sehingga mengakibatkan rusaknya porin, sel bakteri akan kekurangan nutrisi, sehingga pertumbuhan terhambat atau mati. Senyawa alkaloid memiliki mekanisme kerja dengan cara menghambat, menganggu komponen penyusun peptidaglikan pada sel bakteri sehingga lapisan dinding sel tidak terbentuk secara utuh dan menyebabkan kematian sel tersebut. ${ }^{14}$ Senyawa fenolat dalam daun cengkih, yaitu eugenol minyak daun cengkih yang mengandung eugenol merupakan bagian dari phenyloporis yang diduga dapat menghambat pertumbuhan bakteri melalui interaksi membran. ${ }^{15}$

Beberapa faktor yang dapat memengaruhi mutu ekstrak, salah satunya yaitu faktor lingkungan, seperti radiasi matahari, suhu tanaman, ketersediaan air, dan kecukupan cahaya dalam proses fotosintesis yang dapat mengganggu fungsi fisiologis dan siklus hidup tumbuhan. Faktor lingkungan ini yang mungkin memengaruhi senyawa-senyawa yang terdapat pada daun cengkih. Kriteria daun cengkih yang digunakan dalam penelitian ini yaitu daun cengkih tua, pada umumnya permukaan daun berwarna lebih tua dan mengkilap. ${ }^{16}$ Hal ini menunjukkan bahwa pada permukaan daun mengandung banyak minyak atrisi. Kemampuan ekstrak daun cengkih dalam menghambat bakteri Enterococcus faecalis termasuk kurang kuat bila dibandingkan dengan antibiotik metrodinazole. Hal ini mungkin dikarenakan konsentrasi kepekaan pada ekstrak daun cengkih belum diketahui Minimal Inhibitor Concentration (MIC) terhadap bakteri Enterococcus farcalis, sehingga zona hambat yang terbentuk belum sebanding dengan zona hambat pada antibiotik metrodinazole sebagai kontrol positif. Terdapat banyak penelitian yang telah dilakukan untuk membuktikan daya hambat daun cengkih dengan MIC. Salah satunya ialah penelitian yang dilakukan Kumala dan Indriani $^{17}$ terhadap bakteri Gram positif (Staphylococcus aureus dan Bacillus subtillis) dan bakteri Gram negatif (Esherichia coli dan Salmonella parathyposa) menunjukkan bahwa dengan konsentrasi $1 \%$ belum menunjukkan adanya daya hambat pada media pertumbuhan, sedangkan pada konsentrasi $10 \%$ dan $20 \%$ menunjukkan adanya daya hambat pada media pertumbuhan.

\section{SIMPULAN}

Ekstrak daun cengkih (Syzygium Aromaticum L.) memiliki daya hambat yang tergolong sedang terhadap pertumbuhan bakteri Enterococcus faecalis.

\section{SARAN}

Perlu dilakukan penelitian lebih lanjut mengenai efektivitas daun cengkih (Syzygium Aromaticum L.) terhadap bakteri Enterococcus faecalis pada berbagai konsentrasi kepekatan ekstrak sehingga dapat diketahui minimal inhibitor concertration ekstrak terhadap bakteri Enterococcus faecalis.

\section{DAFTAR PUSTAKA}

1. European Society of Endodontology. Quality guidelines of endodontic treatment: 
consensus report of the European Society of Endodontic. Endo J. 2006;39:921-30.

2. Harly FJ. Endodontic Clinic (3rd ed). 2010; p. 128 .

3. Thakur S, Paulaian EJ. Evaluation of mineral trioxide aggregate as root canal sealer: a clinical study. J Conserv Dent. 2013;16(6):494-8.

4. Jaju S, Jaju PP. Newer root canal irrigants in horizon: a review. Int $\mathbf{J}$ Dent. 2011;2011:851359.

5. Bhardway BS. Role of Enterococcus faecalis influre of endodontic treatment. Int. Curr Microbiol Appl Sci. 2013;2(8)

6. Athanassiadis B, Abbott PV, Walsh LS. The use calcium hidroxide, antibiotics and biocides as antimicrobial medicaments on endodontics. Aust Dent J. 2007;52(1Suppl):S64-82.

7. Kayaoglu G. Orstavik, D. Virulence factors of Enterococcus faecalis: relationship to endodontic disease. Crit Rev Oral Biol Med. 2004;15(5): 308-20.

8. Pratiwi GA. Uji daya hambat ekstrak daun cengkeh (Syzygium Aromaticum (L.) Merr \& LM Perry) terhadap pertumbuhan Candida albicans [Skripsi]. Manado: Universitas Sam Ratulangi; 2015

9. Kurniawan A, Rahayu S, Wahtuningrum R. Perbandingan kadar eugenol minyak atrisi daun cengkeh (Syzygium Aromaticum (L) Merry \& Perry) yang tumbuh di dataran tinggi dan dataran rendah. Jurnal Pharmacy. 2009;6(3).

10. Haryani D. Berkumur ekstrak daun cengkeh (Eugenia Aromaticum) 4\% dapat menurunkan jumlah koloni bakteri dan bakteri Staphylococcus Aureus pada abses submukus. Denpasar: Universitas Udayana; 2015.

11. Pahkla ER, Koppel T, Saag M, Pahkla R. Metrodinazole concentrations in plasma, saliva and periodontal pockets in patiens with periodontitis. J Clin Periodontology. 2005;32(2):h. 163-6.

12. Juliantina FR. Manfaat sirih merah (Pipper croatum) sebagai agen antibakteri terhadap bakteri Gram positif dan Gram negatif. JKKI. 2008;1(3):3-8.

13. Makar HPS. Effect and fate of tannins in ruminat animals, adaptation to tannins and strategies to over detrimental effects of fedding tannin rich foods. Animal Production of Health Section, Joint FAO/IAEA Division. Vienna, Autria: International Atomic Energy Agency, 2003; p. 241-56.

14. Ajizah A. Sensitivitas Salmonella typhimiurium terhadap ekstrak daun Psidum Guajava L. Bioscientiae. 2004;1(1):31-8.

15. Nurdjanah N. Diversifikasi penggunaan cengkeh Perspektif. 2004;3(2):61-70.

16. Hilmanto R. Indikator ekologi pada waktu tanaman sebagai inovasi masyarakat lokal dalam menghadapi dampak negatif perubahan iklim. Available from: portalgaruda.org/article.php? article $=61763 \& \mathrm{val}=4556$

17. Kumala S, Indira D. Efek antibakteri ekstrak etanol daun cengkeh (Eugenia aromatic L.). Jurnal Farmasi Indonesia. 2008;4(2):84-6. 